\title{
Brexit - Populist Reaction to the 2008 Speculative Bubble Bursting?
}

\author{
EJAN MACKAAY
}




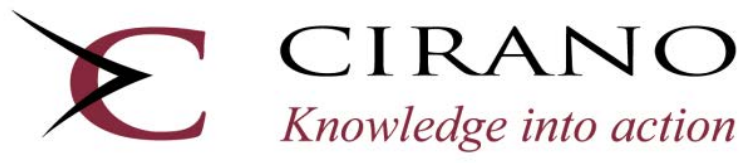

Center for Interuniversity Research and Analysis on Organizations

The purpose of the Working Papers is to disseminate the results of research conducted by CIRANO research members in order to solicit exchanges and comments. These reports are written in the style of scientific publications. The ideas and opinions expressed in these documents are solely those of the authors.

Les cahiers de la série scientifique visent à rendre accessibles les résultats des recherches effectuées par des chercheurs membres du CIRANO afin de susciter échanges et commentaires. Ces cahiers sont rédigés dans le style des publications scientifiques et n'engagent que leurs auteurs.

CIRANO is a private non-profit organization incorporated under the Quebec Companies Act. Its infrastructure and research activities are funded through fees paid by member organizations, an infrastructure grant from the government of Quebec, and grants and research mandates obtained by its research teams.

Le CIRANO est un organisme sans but lucratif constitué en vertu de la Loi des compagnies du Québec. Le financement de son infrastructure et de ses activités de recherche provient des cotisations de ses organisations-membres, d'une subvention d'infrastructure du gouvernement du Québec, de même que des subventions et mandats obtenus par ses équipes de recherche.

\section{CIRANO Partners - Les partenaires du CIRANO}

Corporate Partners - Partenaires corporatifs

Autorité des marchés financiers

Bank of Canada

Bell Canada

BMO Financial Group

Business Development Bank of Canada

Caisse de dépôt et placement du Québec

Desjardins Group

Énergir

Hydro-Québec

Innovation, Science and Economic Development Canada

Intact Financial Corporation

Laurentian Bank of Canada

Manulife Canada

Ministère de l'Économie, de la Science et de l'Innovation Ministère des finances du Québec

National Bank of Canada

Power Corporation of Canada

PSP Investments

Rio Tinto

Ville de Montréal

Academic Partners - Partenaires universitaires

Concordia University

École de technologie supérieure

École nationale d'administration publique

HEC Montréal

McGill University

National Institute for Scientific Research

Polytechnique Montréal

Université de Montréal

Université de Sherbrooke

Université du Québec

Université du Québec à Montréal

Université Laval

CIRANO collaborates with many centers and university research chairs; list available on its website. Le CIRANO collabore avec de nombreux centres et chaires de recherche universitaires dont on peut consulter la liste sur son site web.

(C) March 2020. Ejan Mackaay. All rights reserved. Tous droits réservés. Short sections may be quoted without explicit permission, if full credit, including (C) notice, is given to the source. Reproduction partielle permise avec citation du document source, incluant la notice (C).

The observations and viewpoints expressed in this publication are the sole responsibility of the authors; they do not necessarily represent the positions of CIRANO or its partners. Les idées et les opinions émises dans cette publication sont sous l'unique responsabilité des auteurs et ne représentent pas nécessairement les positions du CIRANO ou de ses partenaires. 


\title{
Brexit - Populist Reaction to the 2008 Speculative Bubble Bursting? *
}

\author{
Ejan Mackaay ${ }^{\dagger}$
}

\begin{abstract}
Résumé
As evidence accumulates about the harmful effects Brexit is likely to cause to the British economy, one may wonder what made a majority of Brits vote to leave the EU. Rather than treat it as a fit of ill temper or an unfortunate accident, this paper explores the idea that it should be seen as a populist reaction triggered by the burst of the speculative bubble in 2008-2009 and the subsequent economic mayhem.
\end{abstract}

To make the case, the paper looks at (1) what populism is, (2) how it can arise as part of longterm economic waves and (3) what precisely happened in Britain before and after 2009.

Keywords/Mots-clés: Law and Economics, Public Choice, Populism, Technological Revolutions and Bubble Collapses, Brexit

JEL Codes/Codes JEL: K00, B52

\footnotetext{
* The ideas put forth here were originally presented at the Brexit Workshop, 21/22 June 2019, the Bucerius Law School, Hamburg. My thanks to Nanette Neuwahl for comments on an earlier draft.

† Emeritus Professor of Law, Université de Montréal; Fellow, CIRANO; ejan.mackaay@umontreal.ca; ejan.mackaay@cirano.qc.ca
} 
One day somebody will explain to me why it is that, at a time when science has never been wiser, or the truth more stark, or human knowledge more available, populists and liars are in such pressing demand. John Le Carré Speech in acceptance of the 2019 Olof Palme Prize on 30 Jan 2020 The Guardian 20200201 https://www.theguardian.com/books/2020/feb/01/john-le-carre-breaking-heartbrexit?CMP=Share iOSApp Other\&fbclid=IwAR2owbSXBkg-4 sJltBKIsDe0DepU1lokEFJDKGWSxbbtQLWtbQNMF8dTI 


\section{Introduction}

The Brexit Referendum took place on 23 June 2016. Of the total number of votes cast, $51.9 \%$ favoured Leave. London and other large cities, Scotland and Northern Ireland voted predominantly in favour of Remain. ${ }^{2}$ On 29 March 2017, Prime Minister May invoked article 50 of the Treaty on European Union, ${ }^{3}$ triggering the process of disengaging the United Kingdom from the European Union. The departure date would be two years after article 50 was invoked, i.e. 29 March 2019. That date was extended to 31 October 2019, and again to 31 January 2020, when the departure was formally consummated, as the newly elected Prime Minister Johnson expressly wanted it to happen. The Prime Minister has expressed the hope of concluding within the current calendar year the negotiations aimed at defining the relationship between the UK and the EU for the future.

The formal departure puts an end to what was an uneasy relationship from the beginning. When the original six founding nations of what is now the European Union convened in the 1950s to explore the possibility of a free-trade union, a common market, Germany and France had good reasons for wanting such a union after the Second World War; Britain, through the voice of Eden, Secretary for Foreign Affairs and then Prime Minister, felt that for the victor of the Second World War this pond was too small and that Britain should continue to play a role in every corner of the world. ${ }^{4}$ By the 1960 s, the common market was a success. Prime Minister Macmillan, replacing Eden after the Suez Canal disaster, took a more realistic view of Britain's future place in the world. But it fell

2 Opinion polls taken since the Brexit vote, as the implications of Brexit became clearer, indicate that a majority of respondents would have voted in favour of Remain, had a second referendum been held. For instance, 25 May 2018 (Prospect); 10 Aug 2018 (Business Insider); 17 Oct 2018 (Evening Standard); 16 Nov 2018 (The Independent); 8 Dec 2018 (The Independent); 3 May 2019 (The New European); 19 Oct 2019 (Business Insider).

3 Treaty on European Union (2007) https://eur-lex.europa.eu/legal-content/EN/TXT/?uri=celex\%3A12012M\%2FTXT .

4 Stephens in the Financial Times of 31 January 2020. 
to Prime Minister Heath, a convinced European, to bring about Britain's accession to the Common Market in 1973.

His successors lent tepid support to the common market, until Prime Minister Thatcher, from 1979 on, who felt that it opened windows of opportunity for business that Britain otherwise would not have. But she felt uncomfortable with plans for further political integration put forth by European Commission President Jacques Delors and voiced her opinion in the famous 1988 Bruges Speech. ${ }^{5}$ She forcefully negotiated a reduction in Britain's contribution to the common market, which did not earn her great friendship on the continent. Her successor, John Major, was party to the negotiation of the Maastricht Treaty, in which he succeeded in reserving opt outs for Britain on the common currency and on the passport-free travel zone (Schengen). The Treaty allowed those members who sought further integration to move forward, yet leaving Britain, whilst not taking part in those initiatives, well established as part of the club. Prime Minister Blair pursued various initiatives of integration with the continent. He favoured extending the common market eastward and then letting the citizens of those countries, in particular the Poles, freely move to Britain to work, as they did in numbers.

PM Blair ran into heavy seas when he sided with the US to invade Iraq, where the rest of the Common Market refused to go along. This was grist to the mill of Eurosceptic media and a Eurosceptic group within the Conservative Party. In 2007 he had to resign and his position as PM was taken over by Gordon Brown. The consequences of the 2008 worldwide financial crash and the massive influx of migrant workers from central and eastern Europe were perceived negatively within Britain and blamed on "Brussels". Gordon Brown, in turn, resigned in 2010 and the subsequent election saw the Conservatives back in power, with substantial support for the extreme Eurosceptic UKIP party in elections from 2013 to 2015. The new PM, David Cameron, had to accommodate pressure from the Eurosceptic wing in his party, who demanded a 
referendum on Britain's membership of the EU. ${ }^{6}$ Most unfortunately, Cameron decided to give in to this pressure at the very time when the effects of the financial crisis of 2008 led to the eurozone crisis, shaking the EU and testing the cohesion of the leadership, and when in Britain his government had introduced an austerity programme cutting back on various social welfare programmes. No special deal therefore for Britain, which could be perceived in Britain as "inflexible Brussels" squeezing the Brits. So up to the referendum it went, with the result that we know.

Following the unexpected referendum result, the Observer newspaper asked one of its reporters, Carole Cadwalladr, to return to the village of Ebbw Vale, in South Wales, where she grew up. ${ }^{7}$ The village had one of the highest percentages of leave votes (62\%). In the last century, it had been a mining and steel mill village with polluted air. With the closure of the mines and the mills, the village had gone into decline, with lots of jobs lost. It had benefited from an EU policy of subsidising regeneration of such communities. As a result, it had a new College of Further Education, a new Sports Centre, a new railway station and an elaborate road improvement scheme, all funded with EU money, with large signs reminding everyone of that contribution.

When the journalist asked a young villager about to go into the Sports Centre why he had voted Leave, the answer was that the EU never did anything for him personally. Older villagers said similar things and also mentioned the threat of migrants coming into Britain. As the village itself had virtually no foreigners, the journalist wanted to find out what would have given the villagers the idea that they were going to be flooded with migrants. She discovered that the villagers had received political ads and selected news items suggesting that the EU was about to let Turkey in as a member, which would lead to lots of Turkish migrants. Intrigued, she tried to trace those videos, but they were nowhere to be found. After much investigative work, she discovered that these videos were funded by recycled money on the Leave side and individually targeted on the internet to

6 'The irony is we got things right by 2015': UK' Brussels envoys on Brexit, The Guardian, 31 Jan. 2020.

7 https://www.facebook.com/officialjon/videos/881066405575366/?type=2\&theater; https://www.facebook.com/watch/?v=881066405575366. 
persons who had been identified by their internet activities (analysed by Cambridge Analytica and such) as liable to being swayed by them (vulnerable swing voters). Parliamentary demands forced Facebook to make those videos available to investigators. The moneys spent on them did not enter into any tallies of legally admissible campaign expenses.

The point here is not to labour the obvious implications for democracy. What concerns us here is the dynamic by which a significant portion of the popular vote is turned against what, at first blush would seem beneficial to the voters concerned, such as EU contributions to the revival of their village or the EU initiatives to stop overfishing of herring in the North Sea and allow the depleted stock to regenerate, ultimately beneficial - though painful in the short run - to the fishermen at Britain's east coast. People's fears and frustrations were turned into a "cause" for which misguided but symbolically powerful remedies were proposed, billed as giving them back control. That dynamic is called populism.

In what follows, we look in more detail at what populism is (I), why it occurs at this juncture, yet was unforeseen a decade ago (II) and why one might see current developments in Britain as an expression of populism (III).

\section{Populism}

A recent Swedish publication identifies populism by three characteristics. First, holders of populist views identify not so much as individuals but rather as members of a group, "the people", who have been despoiled by another group, the "establishment" or the "elite", composed of aristocrats, bureaucrats or experts. The populist credo aims at getting back control for the people ${ }^{8}$. Second, in order for the "people" to exercise that control, the credo favours majority rule "without speed bumps". The general will of the people, in the sense that Rousseau intended to give to that concept, ${ }^{10}$ is most clearly expressed by majority decision, overriding as much as possible institutional constraints,

\footnotetext{
8 Timbro 2019, 10; Mudde 2017a, 16.

9 Timbro 2019, 10.

10 Rousseau 1762, Book II, Chapter III.
} 
including protection of minority views. Thirdly, to further the implementation of the general will, the populist credo generally favours a strong State. ${ }^{11}$ By the same token, it opposes, as erosions of the power of the people and of the State protecting it, globalisation, free trade, supra-national and international organisations (such as the EU, the Council of Europe and NATO) and immigration into the country in numbers.

Populist reactions threaten to undermine the norms and institutions that are the bedrock of the representative democracy. ${ }^{12}$ Where populists take power, they may stifle cooperation amongst developed nations; encourage bigots; undermine trust in society and ethnic tolerance; replace an atmosphere of reciprocal compromise to find a consensus by policies of division and polarisation, characterised by animosity, hate and fear..$^{13}$ Current economic knowledge suggests that implementing those views will be detrimental to the national economy, and more particularly to the very citizens supporting such views.

Populism is not in itself an encompassing world view, but rather a "thincentred ideology". It needs to be complemented by a proper political ideology, either left of centre ${ }^{14}$ or right of centre ${ }^{15}$. Populism is not opposed to democracy, ${ }^{16}$ but wants it limited to majoritarian decision-making that can possibly override an independent judiciary, a free press, fundamental rights and the rule of law as well protections for different minorities within the population. ${ }^{17}$ Populism is opposed to elitism and to pluralism. ${ }^{18}$ Yet it is not to be assimilated with fascism ${ }^{19}$.

Whilst populism is often presented as having only negative connotations, it can in some cases revitalise a democracy by giving voice to those left behind, where the elites are unresponsive to popular concerns, where State officials are

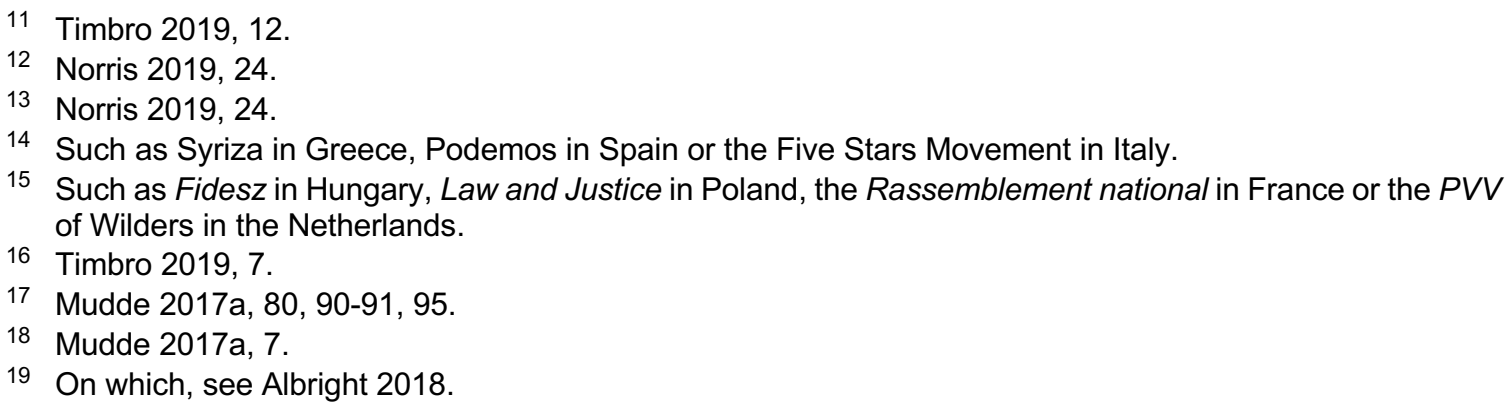


open to corruption, where the State organisation shows other major flaws or where a major economic downturn or stagnation is left unattended. Rajan has recently drawn attention to this positive role. ${ }^{20}$

Populist movements arise in a number of representative democracies even where a variety of indices of citizens' wellbeing point to a continuous improvement. ${ }^{21}$ In an extensive survey published in November 2018, the Guardian reported a substantial breakthrough of populist tendencies throughout the 28 countries that form the European Union. ${ }^{22}$ The same tendency is observed in North America. ${ }^{23}$

These societies are the envy of individuals who happen to be born in countries that are developing or embroiled in civil war, and who, thanks to the internet, can see at any moment how much more agreeable life is in those representative democracies. Large numbers of such individuals attempt by all possible means to get into those advanced societies, creating an influx of refugees, asylum seekers and simple migrants.

Within these societies, citizens were, until quite recently, optimistic that progress would continue and would be beneficial to all willing to make an effort, as summarised in the famous dictum that a rising tide lifts all the boats. The rise of the populist movements questions that optimism and is a source of division within the population.

Why let oneself be seduced by a populist perspective? After all, "[e]ven with their shortcomings, human beings are not irrational automata. "24 It is not, as field studies confirm, a matter of being economically totally ruined..$^{25}$ The safety nets and the assistance programmes put in place in developed economies for the benefit of those left behind by economic development do their job. ${ }^{26}$ The field studies suggest that the populist reaction may be due to cultural resentment, the

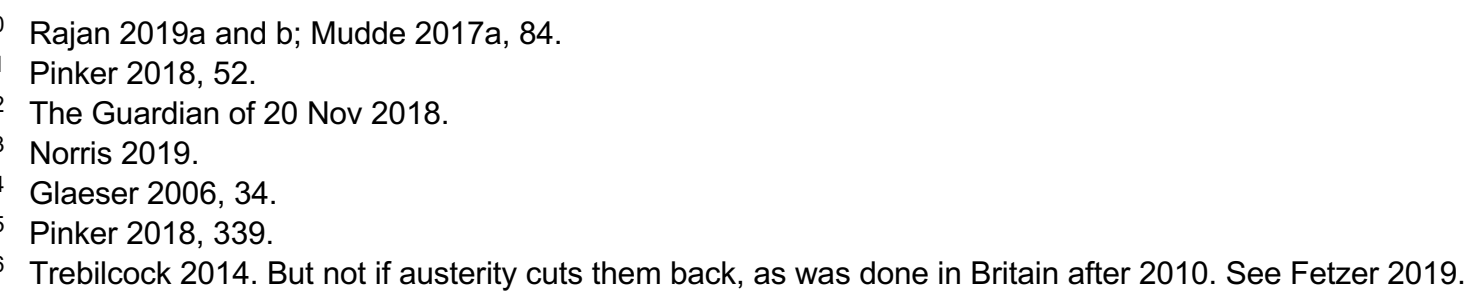


feeling of being left behind, ignored, in what is perceived as an undeserved, stagnant situation, undermining one's certainties. ${ }^{27}$

Some individuals see their situation as stagnant or their job at risk of disappearing. Feeling under threat triggers a self-defence mechanism in humans: look for information on the threat and determine and undertake protective action so as to reduce the weight of the threat. Economically, one seeks the optimal trade-off between the cost of information, the cost of appropriate self-protective measures and the reduction of the cost of the threat they entail. ${ }^{28}$ The cost of informing oneself varies amongst individuals and is likely to be highest amongst the least educated. Surveys show populist beliefs to be most prevalent amongst older individuals, with less education, owners of small businesses, members of the majority group (white, in Northern countries), men more than women, more religiously inclined than the majority and residing in smaller communities rather than large urban agglomerations. ${ }^{29}$

The latter, unable to understand why this misfortune is befalling them and why they deserve this, and to discover how to overcome it, feel betrayed by "the system", live in fear, are angry, no longer trust the system. The latter may accept to believe simplified stories about the origin of the threat and ways to counter it, as supplied by crafty populist politicians. The simplified stories may involve hatred of groups (such as immigrants) or developments depicted as the sources of the ills that befall the believers. ${ }^{30}$ They may look for a strong leader who will protect them and not betray them.

Their insecurity is fanned by the media. The media have a tendency to report whatever goes wrong or does not work well in society. That ten thousand flights have taken off and landed safely today may be a miracle, but it is not news worth reporting. By contrast, the one flight that landed with some difficulty or on the ground needed an emergency evacuation of all passengers is worth reporting, much as on the overall scale of flying, it is a negligible quantity, a catastrophe

27 Margalit 2019; Ocampo 2019; Norris 2019; Ignatieff 2018. Fetzer 2019 insists on the properly economic triggers of the phenomenon.

28 See Glaeser 2005, 53, developing a formal model on the origin of hatred.

29 Pinker 2018, 340; Inglehart 2017, 446, reporting European Social Survey data.

30 Glaeser 2005. 
has been avoided and for which one knows how to prevent a repetition. Why is such an isolated incident news? Our mind tends to retain as representative of a class of events the last one that came to our attention or the one that, brought to our attention, appeals to our sense of self-protection. Psychologists refer to the phenomenon as the availability heuristic. ${ }^{31}$

Individuals worried about their current situation easily find on social media others who share their worries. ${ }^{32}$ The shared worries become a collective fear that clever politicians can verbalise, fan and exploit, pretending that they have a 'solution'. Even if the political party they represent does not come into power, they may displace the focus of the political debate in their own direction, since the other political parties do not wish to appear ignorant or unconcerned by the collective fear and so lose part of the voters.

The phenomenon is by no means novel. Populist tendencies are thought to be present at all times, but generally remain in the background, being favoured by only a small minority of the population. Major blow-ups of populism do not arrive randomly, like bouts of flu. It is during major disturbances or crises that they are thought to become attractive to substantial portions of the population, as they lose faith in current political structures and the persons running them, and fear for their own future. Severe shocks in the economy may bring this pot to a boil, driving many more individuals to go for populist perspectives. Currently, a new urgency may have been given to the populist reactions by the speed of technological change, globalisation, the disappearance of existing jobs and the creation of new ones requiring new skills, the increasing flow of migrants, instant information on anything that moves on the planet and, in particular, by the severe financial crisis following the bursting of a speculative bubble in 2008, which we will now look at in more detail. ${ }^{33}$

\footnotetext{
1 Pinker 2018, $41 \mathrm{f}$.

32 Norris 2019, 17, speaks of the echo chamber of social media.

33 Perez 2009.
} 


\section{Economic long waves, bubbles and populist shocks}

The idea of economic development in waves, accompanied by bursting speculative bubbles, has been put forth recently in particular in the work of Perez. ${ }^{34}$ The starting point is the observation that the lot of humanity improves through technical innovations that disturb the established ways of doing things, and their dissemination throughout society. Over the past two and a half centuries, these innovations have come about in the form of massive and concentrated bursts of inventiveness, roughly every 50 to 70 years, that widely upset the established way of doing things - including markets - that were held to be obvious and immutable until then.

Perez sees five such waves since the Industrial Revolution. The first one starts with the Industrial Revolution in England, around 1770, mechanising the cotton industry and introducing the first machines; for the distribution of the new products, it led to the digging of canals and the building of toll roads.

From around 1830 on, there is a new wave of innovation due to the introduction of steam engines running on coal; it leads to the first railroads, universal postal and telegraph services. By 1875, a third wave starts with the mastery of steel, electricity and heavy engineering; it leads to the first massive globalisation due to steam ships that could span the globe in a relatively short time. A four wave takes off around 1910 with gasoline motors, cars, mass production and urban sprawl. Finally, from around 1970 we see the revolution of information and communications technologies, miniaturised to be accessible in all objects. ${ }^{35}$ Together these revolutions have allowed citizens in developed countries to improve their welfare thirty times or more. ${ }^{36}$ And the process of enrichment continues and has started in most other parts of the world as well.

34 Perez 2003; 2009; 2010; 2017; 2018. Perez belongs to the Neo-Schumpeterians, amongst whom one also finds Christopher Freeman and Mariana Mazzucato.

35 Perez 2003, 18, 57. For more details, see Denning 2018, Box 12-1 The history of golden ages and nuclear winters, and the text of chapter 12.

36 McCloskey 2016, XIV, who calls it The Great Enrichment, explaining that this enrichment (by a multiplying factor of 30 to a hundred, that is $3000 \%$ to $10000 \%$, depending on the region) by far exceeds any earlier one in the course of human history. See also McCloskey 2019. 
Although these waves do not unfold according to a fixed pattern, it is nonetheless possible to recognise some recurrent phases. At the outset, there is a situation in which known technologies and know-how are well disseminated, have reached their cruising speed and do not seem to lend themselves to new highly profitable breakthroughs. Adventurous minds, relying on new and as yet unexploited scientific discoveries, are getting impatient and look for openings to launch radically new products, technologies, ways of doing things.

If they find the openings, they face the problem of financing the development and implementation of the new ways. Since the new ways deviate from the established order and have unknown potential and chances of success, may be difficult financing through the regular sources of capital and will have to be found in risk capital. Venture capitalists will have to be persuaded and substantial returns on capital will have to be promised in case of success, given the substantial risk of the ventures. If the first ventures are successful, they may have a snowballing effect and convince other adventurers to try their chance, other financiers to provide risk capital for their projects. In due course this may lead to a frenzy of inventiveness and innovation, accompanied by a speculative bubble amongst the financiers looking for the most profitable venues. During the current revolution, the financial frenzy has taken on worldwide proportions thanks precisely to the advances in information technology that are being revolutionised. Perez speaks of a financial casino spanning the globe. ${ }^{37}$ The bubble finally burst in 2008.

Taken together, these activities form what Perez calls the installation period of the emerging new technologies. To help it along, its promoters ask the State for deregulation and tax advantages, as much for products and production, as for the financial sector supporting them - a liberal agenda. These demands are accepted because of the increase in welfare they promise for society as a whole. For the traditional industries, these developments increase the pressure for greater profitability, to keep up with the returns in the new tech sector:

37 Perez 2010, 3. 
rationalisation, increased streamlining, higher productivity, abolition of 'dead wood' positions. The alternative is to stagnate and disappear or be taken over.

The overflowing enthusiasm for the new technologies and the capital that is thrown at them risks creating a speculative bubble. The bubble ends up bursting, causing serious losses amongst the adventurers and the investors (although some succeed admirably in extricating themselves in time) and bankruptcies in cascade amongst the innovators as much as amongst established industries, with spillover effects on large segments of the population that are not involved in the innovation wave. Jobs in traditional industries become stagnant or are lost.

The bursting of the bubble is a turning point, since it risks generating amongst a substantial proportion of the population the perception of being powerless in the face of these developments and left to fend for themselves, whilst they see others benefiting, through corruption ${ }^{38}$ or escape routes known only to them. ${ }^{39}$ Persons left out in the cold in this way may be tempted to support populist propositions promising 'solutions', possibly simplistic, to the problems that they are living through. ${ }^{40}$ The international economic order could be grounded as a result of protectionist measures.

On this view, a populist fringe may exist all the time, but populism may go through an upsurge precisely at the turning point of the wave, where massive innovations, in a scarcely controlled frenzy and supported by parts of the population who stand to gain by it, massively perturb existing ways organising industry and producing things, and then pop, leaving in the process a substantial portion of the population out in the cold. The political consensus is blown to pieces; one observes profound divisions that look irreconcilable, as they were in the years following 1793,1848 , the panic of $1893^{41}$, starting a massive recession, 1929 and again, in our day, 2000 (NASDAQ imploding) and then, more dramatically, 2008, giving rise, amongst other reactions, to the populist Trump presidency in the United States and the Brexit vote in Britain. The danger is that

38 There's a reason for the lack of trust in government and business: corruption - Christine Lagarde, The Guardian, 4 May 2018.

39 Acemoglu 2019, 476.

40 Perez 2018.

41 https://en.wikipedia.org/wiki/Panic of 1893 . 
the populist reaction to the crisis will lead to measures greatly harming the international economic order that generates welfare growth benefiting large parts of the world population. In the 1930s, the economic crisis and the populist response led ultimately to the Second World War.

These developments may have a sunny side. Who would have believed, during the recession of the 1930s, that the crisis would be overcome and that the world would go through a new golden age of steady growth? Yet that is precisely what happened from the end of the war till the end of the 1960s. The explanation is that over time, societies overcome the effect of the crisis that follows the bursting of the bubble. The potential of the new technologies is now better understood, new regulations can be put in place to control speculation and with some state help, one can now direct the new technologies to all the industries amenable to them - a more interventionist agenda. We are then in what Perez calls the deployment phase. Industry and the professions appear to be guided by a new productive paradigm. ${ }^{42}$ Industries that don't fit the new paradigm become niche sectors or disappear. Innovation is more clearly focused and aims at perfecting new products and extend them to new sectors. The new technologies, one might say, evolve towards maturity. The implementation is henceforth financed by regular sources of funding, with relatively circumscribed risks. New regulatory frameworks for the new technologies ensure broadly spread spin-off effects in the form of jobs and stable revenues. This justifies the term golden age in Perez's vocabulary.

Each golden age brings a change in the predominant lifestyle to which aspire the enlightened minds: the great leap in the beginning of the 19th century, the Victorian Age in the middle of that century and the Belle Époque towards its end, the American Dream after the Second World War. In our days the contours of a new lifestyle remain to be filled in. The generalisation of the American lifestyle after the Second World War across the entire planet is simply unsustainable. ${ }^{43}$

42 Perez 2003, 9, 17, 28, 31 explicitly refers to Kuhn 1962, who observed, in the evolution of the sciences, this fluctuation between periods of normal science, during everyone followed the commonly accepted paradigm and science advanced regularly, and moments of crisis of the going paradigm with apparent stagnation, which one gets out of through a scientific revolution leading to a new paradigm.

43 Perez 2018. 
The new lifestyle to be adopted must be accessible for the vast majority of humans on Earth (considering the economic take-off in Asia) and no doubt involve sustainable development, a reduction of our drawing on the earth's natural resources (and more recycling) and a broader appeal to services.

\section{Brexit as a populist reaction}

Reflecting on the Brexit vote, the respected weekly The Economist, in its 2 July 2016 issue, stated:

'Anger at immigration, globalisation, social liberalism and even feminism, polling shows, translated into a vote to reject the EU. As if victory were a licence to spread hatred, anger has since lashed Britain's streets with an outburst of racist abuse.'

To which the equally respected Financial Times added, in its 30 August 2018 edition: 'Populism is the true legacy of the global financial crisis.'

Precisely how did the causality run from the financial crisis of 2008 to the Brexit vote? Most fortunately, the British economist Thiemo Fetzer has done a detailed empirical study of the question. ${ }^{44}$ His data set comprises all elections (local, national and European) between 2000 and 2015, as well as the Brexit vote of 2016. As the dependent variable he uses, as a proxy for support for the Leave option, the percentage of those voting for UKIP (the UK Independence Party, established in the late 1990s, favouring withdrawal from the European Union). Until 2010, the party was a negligible quantity; from 2010 on, it made significant gains.

The economic crisis struck in 2008. Welfare programmes were in place to lend support to the losers in the crisis, ${ }^{45}$ but starting in 2010 the Conservative government in Britain adopted with a severe austerity programme that was consolidated in the Welfare Reform Act of 2012, coming into force in 2013. The austerity measures entailed abrupt cuts in welfare programmes of around $16 \%$ per capita, but leading to actual losses of $23.4 \%$ in real terms between 2010 and

\footnotetext{
44 Fetzer 2019.

45 Fetzer 2019, 3883.
} 
$2015 .{ }^{46}$ Due to the austerity measures, the support for UKIP jumped by between 3.5 and $11.9 \%$, an increase sufficient to tip a majority of voters to favour Leave. ${ }^{47}$

Economic insecurity may have activated grievances that make a vulnerable segment of the population sensitive to populist messages blaming the insecurity on immigrants and on the EU, much as empirical research may show that these are not the causes of the economic misfortune. Sadly, in the 1930s, support for the Nazi Party also dramatically increased in areas particularly exposed to the effects of austerity programmes. ${ }^{48}$

These tendencies can be examined closer up at the district level. Fetzer finds that districts more exposed to import competition from low-income countries show a distinctly higher support for the Leave option. ${ }^{49}$ Generally regions with a larger share of "routine" jobs, "low-educated" residents and high baseline employment in retail and manufacturing saw an increase in support for UKIP after 2010.50

Fetzer highlights the growing skill divide in the British labour market. ${ }^{51}$ The Brexit episode brings out further divides according to age, between the larger cities and the countryside, between England, on one side, and Scotland and Northern Ireland, on the other, as Figures 1 and 2 show. One awaits with some nervousness how these divisions will be overcome in post-Brexit Britain under conservative government.

\footnotetext{
46 Fetzer 2019, 3850.

47 Ibid.

48 Fetzer 2019, 3852 and sources given there.

49 Fetzer 2019, 3853.

50 Fetzer 2019, 3850.

51 Fetzer 2019, 3884.
} 
Figure 1. Division by age ${ }^{52}$ How different age groups voted

\begin{tabular}{|c|c|c|c|}
\hline & Leave & $50 \%$ & Remain \\
\hline $18-24$ & $27 \%$ & & $73 \%$ \\
\hline $25-34$ & $38 \%$ & & $62 \%$ \\
\hline $35-44$ & $48 \%$ & & $52 \%$ \\
\hline $45-54$ & $56 \%$ & & $44 \%$ \\
\hline $55-64$ & $57 \%$ & & $43 \%$ \\
\hline $65+$ & $60 \%$ & & $40 \%$ \\
\hline Source: Lord Ashe & oft Polls & & BBBC \\
\hline
\end{tabular}

52 https://www.bbc.com/news/magazine-36619342 


\section{Figure 2. Division by region ${ }^{53}$}

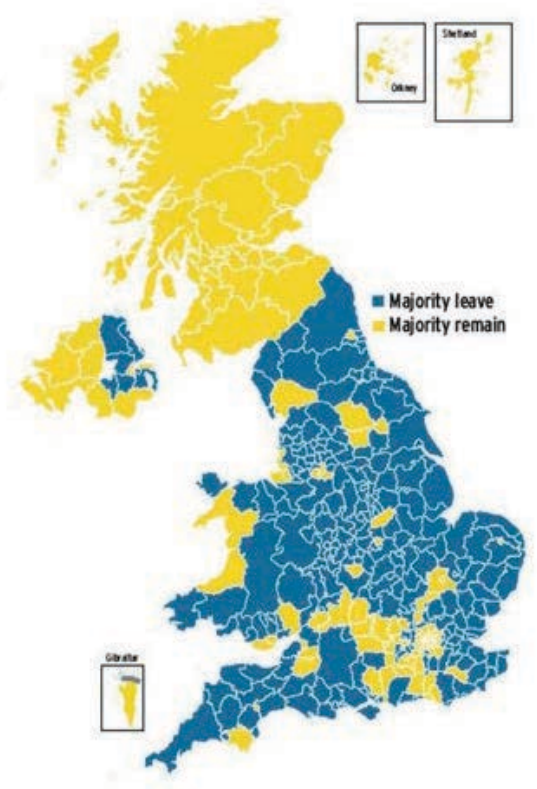

\section{Conclusion}

Britain's membership in the European Union has formally ended on 31 January 2020. What made a narrow majority of Brits (less than $52 \%$ ) vote for Leave, even though membership in the EU has contributed to economic growth in the country and has given easy mobility to older citizens looking to retire in the warmer countries of Europe and to the younger generation seeking complementary higher education elsewhere in Europe through the Erasmus and other programmes? Rather than treat it as a fit of ill temper or an unfortunate accident, this paper explores the idea that it should be looked at as a populist reaction to the burst of the speculative bubble in 2008-2009 and the subsequent economic mayhem.

A first section looks at what populism is. Populism appears to appeal to people whose lives are severely squeezed by causes they do not understand and consider unjust. Populism opposes "the people" to an "elite" adopting programmes that harm the former. In answer to the squeeze, populist leaders

53 https://www.mirror.co.uk/news/uk-news/who-voted-brexit-how-eu-8277077. 
identify what they designate as causes and propose a range of measures to give control back to the people. The causes pointed to do not correspond to what science identifies as such, nor do the measures proposed constitute the most appropriate means for correcting the ills that led to populism.

Why would sensible people go for such populist perspectives? They must be hurt by a severe shock that causes economic grievances to ordinary individuals and severely undermines the certainties on which is based their cultural identity. What could cause such severe shocks? One theory links them to long-term (50 70 years) economic waves, which have led to a thirty-fold increase in wealth over the past two and a half centuries in the developed nations. Five such waves have been identified. Each wave starts with an explosion of inventions and innovations. As these find their way into the industrial and social organisation, they lead to speculative bubbles, which in due course burst, causing widespread and serious economic harm (bankruptcies, jobs abolished, etc.). In each of the five economic waves, the bursting bubble has caused serious dislocation in the years following: 1793,1848 , the panic of $1893^{54}$, starting a massive recession, 1929 and, in our day, 2000 (NASDAQ imploding) and then, more dramatically, 2008.

There is no doubt that the 2008 crisis seriously hit Britain. Its ill effects might have been contained by existing welfare programmes, had not the Conservative government adopted, starting in 2010 , a series of drastic austerity measures that curtailed the safety net of the welfare programmes, compounding the effects of the economic shock. Empirical research shows that the people most hurt were sensitive to messages putting the blame for what befell them on immigrants and on the European Union, though there is no scientific evidence at all that these had caused the mayhem.

If this analysis is correct, what can be done to contain the ill effects of populism? A first thing is better education in the schools against facile beliefs of what makes society tick. Furthermore, it is essential to maintain the safety net of social welfare programmes looking after the losers of economic growth and

54 https://en.wikipedia.org/wiki/Panic of 1893 . 
dislocation. The legal institutions and constitutional safeguards on which the rule of law and the protection of fundamental rights are based must be preserved at all cost. As for the European Union, it should better inform citizens on what it does and how everyone by and large benefits from its actions, in spite of the bureaucracy it entails. ${ }^{55}$ One of the unexpected effects of the protracted Brexit process has been that in the 27 remaining member states, support for the Union has grown. ${ }^{56}$

\section{Bibliography}

Acemoglu 2019 Acemoglu, Daron and James A. Robinson, The Narrow Corridor: States, Societies, and the Fate of Liberty, New York, Penguin Random House, 2019

Albright 2018 Albright, Madeleine, Fascism: A Warning, New York, Harper, 2018

Alesina 2018 Alesina, Alberto F., Armando Miano and Stefanie Stantcheva, Immigration and Redistribution, NBER Working Paper No. w24733, 2018, https://scholar.harvard.edu/stantcheva/publications/immigrationand-support-redistribution

Denning 2018 Denning, Stephen, The Age of Agile: How Smart Companies Are Transforming the Way Work Gets Done, New York, HarperCollins, 2018

Eichengreen $2018 \quad$ Eichengreen, Barry, The Populist Temptation: Economic Grievance and Political Reaction in the Modern Era, Oxford, Oxford University Press, 2018

Fetzer 2019 Fetzer, Fetzer, Thiemo, "Did Austerity Cause Brexit?", (2019) 109 American Economic Review 3849-3886 (https://www.aeaweb.org/articles?id=10.1257/aer.20181164)

Glaeser 2005 Glaeser, Edward L., "The Political Economy of Hatred", (2005) 120 Quarterly Journal of Economics $45-86$

Glaeser 2006 Glaeser, Edward L., "Paternalism and Psychology”, (2006) 29 Regulation 32-38

Guardian 2018 The Guardian, 201811 20, How populism swept through Europe over 20 years, https://www.theguardian.com/world/ng-interactive/2018/nov/20/how-populism-emerged-as-electoral-forcein-europe?CMP=Share iOSApp Other

Inglehart 2017 Inglehart, Ronald F. and Pippa Norris, "Trump and the Populist Authoritarian Parties: The Silent Revolution in Reverse", (2017) 15 Perspectives on Politics 443-454

Ignatieff 2018 Ignatieff, Michael, "Is identity politics ruining democracy?", (2018) Financial Times 20180905

Kuhn $1962 \quad K u h n$, Thomas S., The Structure of Scientific Revolutions, Chicago, The University of Chicago Press [1962], 1970, (2nd ed.)

Margalit 2019 Margalit, Yotam, "Economic Insecurity and the Causes of Populism, Reconsidered", (2019) 33 Journal of Economic Perspectives 152-170

McCloskey 2016 McCloskey, Deirdre N., Bourgeois Equality: How Ideas, Not Capital or Institutions, Enriched the World, Chicago, University of Chicago Press, 2016

McCloskey 2019 McCloskey, Deirdre N., Why Liberalism Works: How True Liberal Values Produce a Freer, More Equal, Prosperous World for All, New Haven, Yale University Press, 2019

Mudde 2017a Mudde, Cas and Cristóbal Rovira Kaltwasser, Populism: A Very Short Introduction, Oxford, Oxford University Press, 2017

Mudde 2017b Mudde, Cas (ed.), The populist radical right: a reader, London, Routledge, 2017

Müller 2018 Müller, Jan-Werner, What is Populism?, Philadelphia, University of Pennsylvania Press, 2016

Norris $2019 \quad$ Norris, Pippa and Ronald F. Inglehart, Cultural Backlash and the Rise of Populism: Trump, Brexit, and the Rise of Authoritarianism Populism, Cambridge, Cambridge University Press, 2019

55 Eichengreen 2018, chapter 12.

56 European Parliament, 23 May 2018, Public Opinion survey finds record support for EU, despite Brexit backdrop (http://www.europarl.europa.eu/unitedkingdom/en/media/news/2018/may18/eurobarometermay18.html ). Also Financial Times of 15062017. 
Ocampo 2019 Ocampo, Emilio, The Economic Analysis of Populism: A Selective Review of the Literature, Universidad Del Cema, Buenos Aires - Documentos de trabajo no 694, 2019, https://ucema.edu.ar/publicaciones/download/documentos/694.pdf

Perez $2003 \quad$ Perez, Carlota, Technological Revolutions and Financial Capital: The Dynamics of Bubbles and Golden Ages, Cheltenham, Edward Elgar, 2003

Perez 2009 Perez, Carlota, "The double bubble at the turn of the century: Technological roots and structural implications", (2009) 33 Cambridge Journal of Economics 779-805

Perez $2010 \quad$ Perez, Carlota, "Technological revolutions and techno-economic paradigms", (2010) 34 Cambridge Journal of Economics 185-202

Perez 2017 Perez, Carlota, Leo Johnson and Art Kleiner, Are We on the Verge of a Golden Age?, Strategy+business, 2017, https://www.strategy-business.com/article/Are-We-on-the-Verge-of-a-NewGolden-Age?gko=fOfed

Perez $2018 \quad$ Perez, Carlota, Techno-economic paradigm shifts, 2018 lecture given at the Ellen MacArthur Foundation Summit, https://m.youtube.com/watch?v=dhNd3tVR1hl

Pinker 2011 Pinker, Steven, The Better Angels of Our Nature: Why Violence Has Declined, New York, Viking, 2011

Pinker 2019 Pinker, Steven, Enlightenment Now: The Case for Reason, Science, Humanism, and Progress, New York, Viking, 2019

Rajan 2019a Rajan, Raghuram G., A Better Populism, Project Syndicate 201902 27, 2019, https://www.projectsyndicate.org/commentary/populist-economic-policies-better-at-local-level-by-raghuram-rajan-201902 ?barrier=accesspaylog

Rajan 2019b Rajan, Raghuram G., Why Capitalism Needs Populism, Project Syndicate 20190506,2019, https://www.project-syndicate.org/commentary/survival-of-capitalism-needs-populism-by-raghuram-rajan2019-05

Rousseau 1762 Rousseau, Jean-Jacques, Du contrat social, livre II, Chapitre III, https://fr.wikisource.org/wiki/Du contrat social/Édition 1762/Livre II/Chapitre 3

Timbro 2019 Timbro, Timbro Authoritarian Populism Index, Stockholm, Timbro, 2019, https://populismindex.com/report/ 